\title{
Zakat Harta Kekayaan dalam Perspektif Tafsir Ayat Ahkam
}

\author{
Husin Bafadhal \\ Universitas Islam Negeri Sulthan Thaha Saifuddin, Jambi \\ e-mail: husinbafadhal@,uinjambi.ac.id
}

\begin{abstract}
ABSTRAK. Fenomena zakat dalam Islam senantiasa mengalami perkembangan seiring dengan kemajuan ilmu pengetahuan dan tekhnologi serta perkembangan aktifitas ekonomi dengan segala macam jenisnya, sehingga memunculkan berbagai persoalan mengenai produk zakat kontemporer dengan bertambahnya jenis harta yang wajib dizakati. Salah satunya adalah zakat harta kekayaan. Penelitian ini dimaksudkan untuk mengkaji dan menganalisis pengembangan makna zakat harta kekayaan dalam perspektif tafsir ayat Abkam. Jenis penelitian ini adalah kepustakaan (library research) yaitu dengan mengumpulkan sejumlah data yang berkaitan dengan zakat badan bukum berupa kitab-kitab fikih, ushul fikih, tafsir, hadis, jurnal dan sumber lain yang berkenaan dengan masalab zakat badan bukum. Analisis data dalam penelitian ini meliputi analisis isi, metode komparatif, dan analisis bermeneutik yang bersifat interaktif. Hasil penelitian menunjukkan babwa kekayaan yang dimiliki seseorang yang bersumber dari usaha ekonomi apa saja usahanya dengan batasan thayyibat (balal dan bermanfa'at), wajib-lah ia mengeluarkan sebagian dari penghasilanny a bagi keperluan orang yang berbak menerimanya.
\end{abstract}

Kata kunci: zakat, harta kekayaan, tafsir, ayat ahkam.

\section{PENDAHULUAN}

Zakat adalah ibadah maliyah ijtima'iyah yang memiliki posisi yang sangat penting, strategis dan menentukan. Zakat juga termasuk salah satu sendi pokok ajaran Islam, ${ }^{1}$ bahkan zakat dan shalat dijadikan oleh al-Qur'an dan Hadis sebagai lambang dari keseluruhan ajaran Islam. ${ }^{2}$ Di samping itu, jika dilihat dari sisi pembangunan kesejahteraan, zakat juga merupakan salah satu instrumen pemerataan pendapatan. Dengan zakat yang dikelola dengan baik, dimungkinkan membangun pertumbuhan ekonomi sekaligus pemerataan pendapatan (economy growth with equity). ${ }^{3}$

Zakat merupakan sumber utama kas negara sekaligus soko guru dari kehidupan ekonomi yang dicanangkan al-Qur'an. Zakat akan mencegah terjadinya akumulasi harta pada satu orang, dan pada saat yang sama mendorong manusia untuk melakukan investasi dan mempromosikan distribusi. ${ }^{4}$

1Zakat merupakan rukun Islam yang ketiga sebagaimana Hadis dari Ibn Umar, Rasulullah SAW

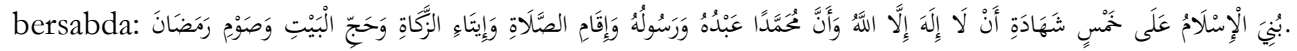
Lihat: Mausu'ah al-Hadis al-Syarif, Shabih Muslim, Kitab: al-Iman, Bab: Bayan Arkan al-Islam wa Da'a'imih al-'Iz̧am, Hadis nomor: 21.

${ }^{2}$ Ismail Muhammad Syah, Filsafat Hukum Islam, (Jakarta: Bumi Aksara, 1992), h. 187.

${ }^{3}$ Ahmad Muflih Saefuddin, Pengelolaan Zakat ditinjau dari Aspek Ekonomi, (Bontang: Badan Dakwah Islamiyah LNG, 1986), h. 99.

${ }^{4}$ Mustaq Ahmad, Etika Bisnis Dalam Islam, Terjemahan Samson Rahman, (Jakarta: Pustaka Al-Kautsar, 2001), h. 75 . 
Secara tegas Allah SW'T melarang terjadinya akumulasi harta di tangan seseorang atau sekelompok orang kaya saja, sebagaimana firman-Nya:

"Apa saja harta rampasan (fai-i) yang diberikan Allah kepada RasulNya (dari harta benda) yang berasal dari penduduk kota-kota Maka adalah untuk Allah, untuk rasul, kaum kerabat, anak-anak yatim, orang-orang miskin dan orang-orang yang dalam perjalanan, supaya harta itu jangan beredar di antara orang-orang Kaya saja di antara kamu. apa yang diberikan Rasul kepadamu, Maka terimalah. dan apa yang dilarangnya bagimu, Maka tinggalkanlah. dan bertakwalah kepada Allah. Sesungguhnya Allah Amat keras hukumannya". ${ }^{5}$

Di dalam al-Qur'an terdapat 82 ayat yang mensejajarkan kewajiban zakat dengan kewajiban shalat. Kalau shalat dikelompokkan sebagai ibadah badaniyyah, maka zakat dikategorikan sebagai ibadah maliyyah. Sebagai ibadah maliyyah, zakat bersentuhan langsung dengan kepentingan kehidupan bermasyarakat. Oleh sebab itu, kalau dengan shalat dibangun kesalehan individual, maka dengan zakat dibangun kesalehan sosial. ${ }^{6}$

Walaupun demikian, tuntunan al-Qur'an dan Hadis dalam persoalan zakat tidaklah selengkap dan serinci tuntunan dalam masalah shalat. Bila shalat diberi Nabi SAW patokan yang jelas dan tegas dengan sabdanya "shallu kama ra-aitumuniy ushalliy" (shalatlah kamu sebagaimana kamu melibatku shalat). Sehingga pelaksanaan shalat, mulai dari takbiratul ihram sampai kepada salam semuanya mengacu kepada apa yang telah pernah dipraktekkan oleh Nabi Muhammad SAW.

Sementara ibadah zakat, belum ada patokan yang terinci dari Rasulullah SAW maupun dari al-Qur'an, kecuali dalam beberapa hal umpamanya dalam hal orang-orang yang berhak menerima zakat (mustahiq) dan dalam hal pengelola (ami). Sedangkan dalam benda-benda apa saja yang wajib dizakati tidak disebutkan al-Qur'an secara terinci. Sekalipun Hadis telah berbicara tentang hal itu namun dirasakan kaum Muslimin belum menyeluruh, sehingga sering mengundang perbedaan yang pro-kontra dalam menetapkannya.

Misalnya "dalam persoalan zakat madu lebah, terjadi perbedaan pendapat; jumhur ulama menetapkan tidak ada kewajiban mengeluarkan zakatnya, karena tidak ada dalil yang menyuruhnya, baik al-Quran, Hadis maupun Ijma'. Sementara Hanafiyah berpendapat tetap ada kewajiban memberikan zakat madu lebah, sekalipun tidak ada satu pun Hadis yang mewajibkannya. ${ }^{7}$ Bila dalam contoh di atas terlihat telah terjadinya perbedaan pendapat, tentu dewasa ini lebih banyak lagi persoalan-persoalan yang muncul yang sebenarnya mengandung potensi zakat yang sangat luar biasa, umpamanya zakat hasil pertanian sawit, kakao dan lain sebagainya.

\section{Pengistilahan dan Substansi Makna Zakat Dalam al-Qur'an}

Ungkapan-ungkapan yang biasa diartikan atau sinonim dengan zakat dalam alQur'an sangat beragam, yaitu zakat, infaq dan sedekah. Adapun rincian ketiga istilah tersebut adalah :

\footnotetext{
${ }^{5}$ Q.S. al-Hasyr : 7.

${ }^{6}$ Amiur Nuruddin, Jamuan Ilabi Pesan al-Quran dalam Berbagai Dimensi Kehidupan, (Bandung : Citapustaka Media, 2007), h. 40.

${ }^{7}$ Sayyid Sabiq, Fiqh al-Sunnah, (Beirut : Dar al-Fikr, 1983), Jilid 1, h.307.
} 


\section{Pengertian Zakat}

Diungkapkan dengan kata zakat dan yang seakar dengannya, terdapat sebanyak 54 kali. Sebanyak 31 kali dengan kata zakat (al-zakat). Tidak satu pun di antaranya yang berbentuk fi'il amar (kalimat perintah), sekalipun ada yang dipahami sebagai amar (perintah) adalah pada kalimat-kalimat yang dijadikan kata zakat itu sebagai objek, terdapat sebanyak tujuh kali atau perintah yang berasal dari khabariyah (kalimat-kalimat berita).

Ditinjau dari segi bahasa (etimologi), kata zakat merupakan kata dasar (isim mashdar) dari kata zakâ (j) mengandung arti berkah, tumbuh, bertambah, bersib, dan baik, sebagaimana yang dinyatakan oleh Sayyidina Ali Karramallah Wajhah: المال تنقصه النفقة والعلم يزكو على الإنفاق,

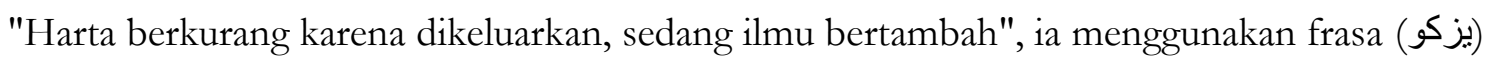
sebagai antonim dari frasa (تنقصد). Masyarakat Arab juga menggunakan kata (أرض زكية) dengan arti bahwa tanah itu baik dan subur, kata (هذا الأمر لا يزكو بفلان) untuk arti bahwa tidak layak bagi si fulan. Menurut Abu Ali: الزكاة صفوة الثيء Sehingga dapat dikatakan bahwa rangkuman arti dari frasa zakat adalah suci (الطهارة), النهوة), tumbuh (النماء), berkah (البركة), dan terpuji (المدح).8

Semua arti tersebut di atas digunakan di dalam al-Quran dan Hadis, ${ }^{9}$ Menurut Ibnu Taimiyah (w. 728 H), jiwa orang yang berzakat akan menjadi bersih dan kekayaannya akan bersih pula. ${ }^{10}$ Hal ini berarti bahwa makna tumbuh dan berkembang itu tidak hanya diperuntukan buat harta kekayaan, tetapi lebih jauh dari itu. Dengan mengeluarkan zakat diharapkan hati dan jiwa orang yang menunaikan kewajiban zakat itu menjadi bersih. Hal ini sesuai dengan firman Allah SWT dalam al-Qur'an surah al-Taubah ayat $103 .{ }^{11}$

Adapun pengertian zakat menurut istilah (terminologi), banyak para ahli fikih memberikan definisi antara lain, menurut Yusuf al-Qardhawi: "Sejumlah harta tertentu yang diwajibkan oleh Allah SWT untuk diserahkan kepada orang-orang yang berhak, di samping berarti mengeluarkan jumlah tertentu itu sendiri”. Jumlah yang dikeluarkan dari kekayaan itu disebut zakat, karena yang dikeluarkan itu menambah banyak, membuat lebih berarti dan melindungi kekayaan dari kebinasaan". ${ }^{12}$

Dengan demikian zakat adalah mengeluarkan sejumlah harta yang telah mencapai nisab dan diberikan kepada orang-orang yang berhak menerimanya. ${ }^{13}$ Zakat juga berarti derma yang telah ditetapkan jenis, jumlah, dan waktu suatu kekayaan atau harta yang wajib diserahkan. Atau zakat adalah nama dari sejumlah harta tertentu yang telah mencapai syarat tertentu (nisab) yang diwajibkan Allah SWT untuk dikeluarkan dan diberikan kepada yang

${ }^{8}$ Muhammad ibn Makram ibn Manzur al-Afriqi al-Mishri, Lisan al-Arab, (Beirut: Dar al-Shadir), Cet I, Jilid XIV, h. 358. selanjutnya disebut Ibn Manzur, Lisan al-Arab.

${ }^{9}$ Pengertian zakat dari sudut etimologi (bahasa) secara lebih mendalam dapat dilihat dalam Yusuf alQardhawi, Fiqh al-Zakah, (Beirut: Dar al-Irsyad, 1969), h. 37. selanjutnya disebut Yusuf alQardhawi, Fiqh al-Zakah.

${ }^{10} \mathrm{Ibid}$.

11“Pungutlah zakat dari kekayaan mereka, engkau bersihkan dan sucikan mereka dengannya...".Q.S. al-Taubah : 103.

${ }^{12}$ Yusuf al-Qardawi, Fiqh al-Zakah, op cit, h. 37-38.

${ }^{13}$ Dalam Undang-Undang Nomor 23 Tahun 2011 tentang pengelolaan zakat pada Bab I Ketentuan Umum pasal 1 ayat 2 menyatakan bahwa zakat adalah harta yang wajib dikeluarkan oleh seorang muslim atau badan usaha untuk diberikan kepada yang berhak menerimanya sesuai dengan syariat Islam. 
berhak menerimanya dengan persyaratan tertentu pula (QS. al-Taubah : 103 dan QS. alRum : 39). ${ }^{14}$

Dinamakan zakat, karena didalamnya terkandung harapan untuk memperoleh berkah, membersihkan jiwa orang-orang yang berzakat dan membersihkan harta. Zakat menciptakan pertumbuhan bagi orang miskin, baik secara material maupun spiritual, serta mengembangkan jiwa dan kekayaan orang-orang yang berzakat untuk kepentingan umum atau mewujudkan kemaslahatan umat di dunia dan imbalan pahala di akhirat. Hal ini sejalan dengan kehendak Allah SWT yang memerintahkan pengambilan zakat dalam surah alTaubah $103 .{ }^{15}$

\section{TEMUAN}

\section{Zakat Harta Kekayaan Dalam Perspektif Tafsir Ayat Ahkam}

Zakat merupakan salah satu rukun Islam, perintah Allah SWT tentang kewajiban mengeluarkan zakat ini dimulai sejak bulan Syawal tahun kedua hijriyah di Madinah. Zakat secara umum terbagi menjadi dua bagian, pertama, zakat harta atau biasa disebut dengan zakat harta (maal) yaitu zakat yang dikeluarkan atas harta yang dimiliki sesesorang atau lembaga dengan syarat-syarat atau ketentuan-ketentuan secara hukum syara' atau harta yang wajib dikeluarkan dari seorang muslim apabila harta tersebut sudah mencapai jumlah tertentu (nisab) dan baul, yang diberikan kepada orang-orang yang berhak menerimanya (mustabiq zakat). Kedua, adalah zakat nafs atau zakat fitrah atau zakat yang diberikan berkenaan dengan telah selesai mengerjakan ibadah puasa Ramadhan. ${ }^{16}$ Zakat diwajibkan berdasarkan dalil dari al-Qur'an, dan Hadis, yaitu:

\section{Nash Al-Qur'an dan Hadis Nabi Muhammad SAW}

Dalam al-Qur'an terdapat 32 kali kata zakat, bahkan sebanyak 82 kali diulang sebutannya dengan memakai kata-kata yang satu sinonim dengannya. Pengulangan tersebut mengandung maksud bahwa zakat mempunyai kedudukan, fungsi dan peranan yang sangat penting. ${ }^{17}$

Dari 32 kali kata zakat yang terdapat di dalam al-Qur'an, 29 kali di antaranya bergandengan dengan kata shalat. ${ }^{18} \mathrm{Hal}$ ini menunjukkan antara zakat dan shalat merupakan kewajiban dalam satu paket, antara keduanya tidak dapat dipisahkan. Pelaksanaan shalat melambangkan baiknya hubungan manusia dengan Allah SWT, sedangkan zakat melambangkan kepedulian sosial dan harmonisnya hubungan manusia dengan sesamanya.

Kata zakat 9 kali diucapkan dalam kontek perintah yang mengiringi shalat, yaitu pada surah: al-Baqarah 43, 83 dan 110, al-Nisa' 77, al-Hajj 78, al-Nur 56, al-Ahzab 33, al-Mujadalah 13, dan al-Muzammil 20.

\footnotetext{
${ }^{14}$ Maksud dari firman Allah SWT dalam al-Qur'an surah al-Taubah : 103 dan al-Rum : 39 adalah bahwa zakat itu membersihkan mereka dari kekikiran dan cinta yang berlebih-lebihan kepada harta benda, dan dengan zakat itu dapat menyuburkan sifat-sifat kebaikan dalam hati mereka, serta memperkembangkan harta benda mereka.

${ }^{15}$ Q.S. al-Taubah : 103.

${ }^{16}$ Sayyid Sabiq, Fiqh al-Sunnah, op cit, h. 276. Lihat juga : Yusuf al-Qardhawi, Fiqh al-Zakah, op.cit., h. 37-38.

${ }^{17}$ Abdurrahman Qadir, op.cit., h. 43.

${ }^{18}$ Ibid,
} 
Sedangkan pengertian zakat dengan menggunakan kata shadaqah sesuai dengan konteknya terdapat 2 ayat, yaitu dalam surah al-Taubah ayat 60 dan 103, yang menggunakan kata Ita' al-haq satu kali, yaitu dalam surah al-Taubah ayat 141, dan penjelasan umum bahwa kewajiban tersebut atas kelebihan kebutuhan pokok, al-afwu, yaitu dalam surah al-Baqarah ayat 219 .

Nash al-Quran tentang zakat diturunkan dalam dua periode, yaitu:

a. Periode Mekkah, dalam tahap ini perintah zakat baru merupakan anjuran untuk berbuat baik kepada fakir miskin dan orang-orang yang membutuhkan bantuan. Di antara ayat al-Qur'an yang menyebutkannya yaitu firman Allah SWT yang berbunyi :

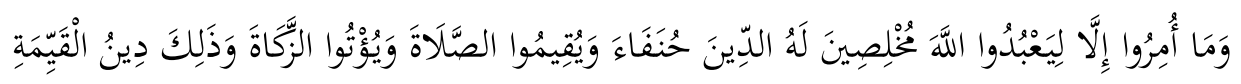

"Padahal mereka tidak disurub kecuali supaya menyembah Allah SWT dengan memurnikan ketaatan kepada-Nya dalam (menjalankan) agama yang lurus, dan supaya mereka mendirikan shalat dan menunaikan zakat; dan yang demikian Itulah agama yang lurus". ${ }^{19}$

Firman Allah SWT dalam al-Qur'an yang berbunyi :

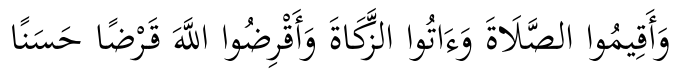

"Dirikan shalat dan tunaikan rakat dan berilah piutang kepada Allah SWT dengan sebaik-baik piutang,"20.

b. Periode Madinah, dalam tahap ini perintah zakat telah menjadi kewajiban mutlak (ilzami). Ayat-ayat zakat dalam periode ini terdapat di dalam berbagai surat di antaranya surat al-Baqarah ayat 43:

$$
\text { وَأَقِيُمُوا الصََّالَة وَءَاتُوا الزَّكَاةَ وَارَكَعُوا مَعَ الرَّاكِعِينَ }
$$

'Dirikan shalat dan tunaikan zakat dan ruku'lah bersama orang-orang yang ruku'. ${ }^{21}$

Firman Allah SWT dalam surat al-Maidah ayat 12 :

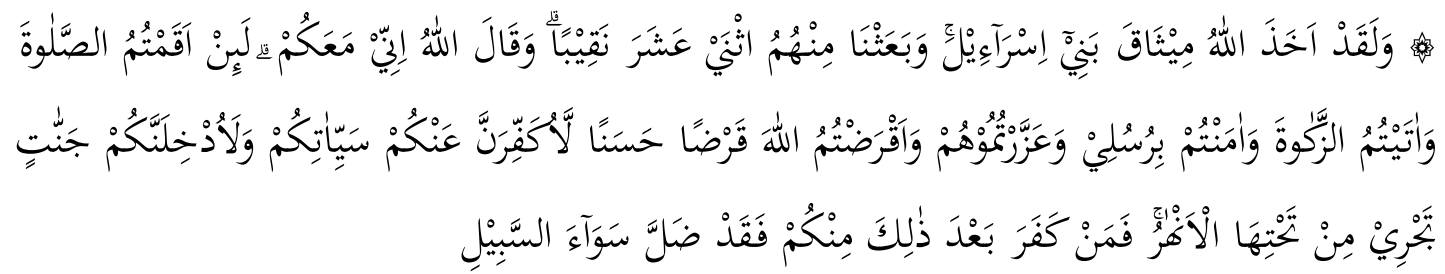

"Dan Sesunggubnya Allah telah mengambil Perjanjian (dari) Bani Israil dan telah Kami angkat diantara mereka 12 orang pemimpin dan Allab berfirman: "Sesunggubnya aku beserta kamu, Sesunggubnya jikea kamu mendirikan shalat dan menunaikan zakat serta beriman kepada rasul-

${ }^{19}$ Q.S. al-Bayyinah : 5.

${ }^{20}$ Q.S. al-Muzammil : 20.

${ }^{21}$ Q.S. al-Baqarah : 43. 
rasul-Ku dan kamu bantu mereka dan kamu pinjamkan kepada Allab pinjaman yang baik Sesunggubnya aku akan menutupi dosa-dosamu. dan Sesunggubnya kamu akan Kumasuk.kan ke dalam surga yang mengalir air didalamnya sungai-sungai. Maka Barangsiapa yang kafir di antaramu sesudah itu, Sesunggubnya ia telah tersesat dari jalan yang lurus". ${ }^{22}$

Dalil yang berasal dari Sunnah Rasul SAW banyak sekali yang menceritakan tentang perintah zakat ini, baik yang langsung diungkapkan dengan menggunakan kata zakat ataupun dengan kata shadaqah. Namun yang jelas kata shadaqah dengan makna zakat banyak ditemukan dalam Hadis Nabi Muhammad SAW, sedangkan kata zakat sering digunakan oleh Rasulullah SAW ketika menjelaskan tentang zakat fitrah. ${ }^{23}$

Di antara Hadis-hadis yang mengungkap tentang zakat ini adalah:

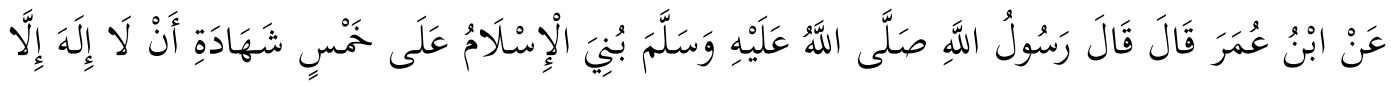

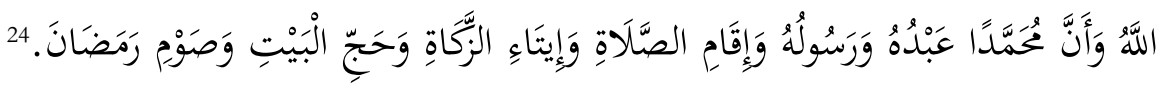

"Dari Ibn Umar r.a berkata bahwa Rasulullah SAW telah bersabda: Islam didirikan dari lima sendi: Mengaku bahwa tidak ada Tuhan yang sebenarnya disembah melainkan Allah SWT dan bahwasanya Muhammad SAW itu adalah utusan Allah SWT, mendirikan shalat, mengeluarkan zakat, mengerjakan haji dan berpuasa di bulan suci Ramadhan".

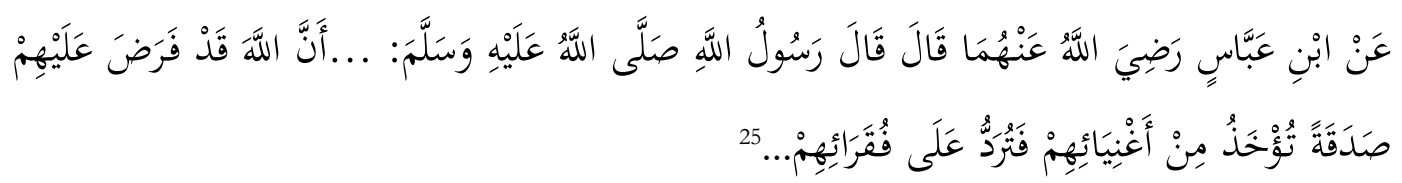

"Dari Ibn Abbas r.a berkata bahwa Rasulullah SAW telah bersabda: ... Sesungguhnya Allah SWT memfardhukan atas mereka untuk mengeluarkan zakat yang diambil dari orang kaya diantara mereka dan diberikan kepada orang-orang fakir diantara mereka ...".

Sehubungan dengan perintah kewajiban zakat ini, Allah SWT berfirman dalam surah al-Taubah ayat 103 yang berbunyi :

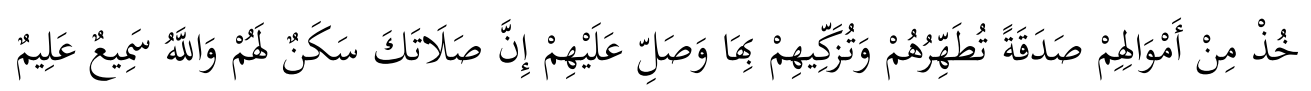

"Ambillah zakat dari sebagian harta mereka, dengan zakat itu kamu membersihkan dan mensucikan mereka dan berdo'alah untuk mereka. Sesungguhnya

${ }^{22}$ Q.S. al-Maidah : 12. Maksudnya Ialah: menafkahkan harta untuk menunaikan kewajiban dengan hati yang ikhlas.

${ }^{23}$ Hadis-hadis tentang kewajiban zakat ini juga diriwayatkan oleh al-Bukhari dari jalur sanad yang lain, seperti Abu Hurairah, Ibnu Abbas, Abu Ayyub, dll. Selain itu juga diriwayatkan oleh Muslim, Abu Daud, Tirmizi, Ibnu Majah dan Ahmad. Lihat: Ibnu Hajar al-Asqalani, Fath al-Bari Syarah Shabih al-Bukhari, (Beirut: Dar al-Fikr, 1991), Jilid IV, h. 4. Lihat juga: Ibnu Daqiqi al-'Id, Ibkam al-Abkam Syarah Umdah al-Ahkam, (Beirut: Dar al-Kutub al-Ilmiyah, tt), Jilid I, h. 182.

${ }^{24}$ Lihat: Muslim, Shabih Muslim, op.cit., h. 683.

${ }^{25}$ Muhammad al-Syaukani, op.cit., h. 170. 
do'a kamu itu (menjadi) ketentraman jiwa bagi mereka. Dan Allah SW'T Maha Mendengar lagi Maha Mengetahui."26

Pada ayat di atas dinyatakan dengan lafal (أموالهم), harta mereka. Kata mereka (ه) disini dapat berarti setiap orang secara individual dan dapat pula diartikan sebagai sekelompok orang. Meskipun para fukaha lebih berorientasi pada harta individu namun tidak menjadikan zakat tersebut harus dan wajib dikeluarkan hanya atas harta individu, sebab, terhadap harta kolektif, yaitu harta beberapa orang yang masih menyatu dalam bentuk harta waris dan harta syirkah usaha juga wajib dizakatkan.

Menurut Ibnu al-Arabi bahwa firman Allah SWT yang berbunyi: "ambillah zakat dari sebagian harta mereka", itu berlaku secara menyeluruh atas semua kekayaan, bagaimanapun jenis, nama dan tujuannya. Orang yang ingin mengecualikan salah satu jenisnya, haruslah mampu mengemukakan satu landasan. ${ }^{27}$

Al-Qurthubi menjelaskan bahwa setiap yang dapat dimiliki oleh seseorang ia disebut harta, dan perintah "ambillah zakat dari sebagian harta mereka" pada ayat di atas dengan menggunakan struktur kalimat mutlak, tidak dikaitkan dengan syarat apapun, baik dari sisi pemberi zakat, harta yang wajib dizakatkan, maupun jumlah yang wajib dikeluarkan zakatnya. Rincian dari perintah dengan struktur mutlak tersebut ditemukan melalui informasi hadis dan $\ddot{j m a} a^{\prime}$ ulama. ${ }^{28}$

Pada prinsipnya semua harta yang berkembang dan diusahakan untuk mendapatkan tambahan adalah wajib zakat, hal ini berdasarkan firman Allah SWT dalam surat al-Baqarah ayat 267 yang berbunyi:

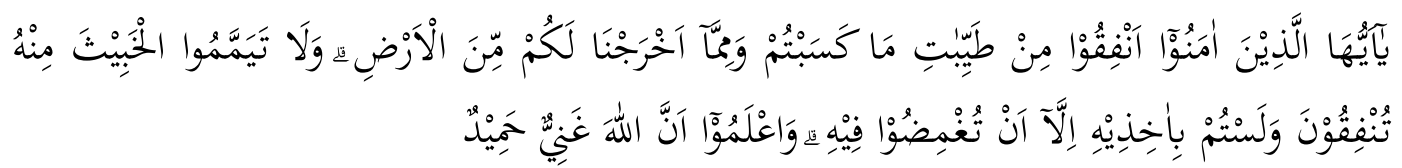

"Hai orang-orang yang beriman, nafkabkanlah (di jalan Allah) sebagian dari hasil usabamu yang baik-baik dan sebagian dari apa yang Kami keluarkan dari bumi untuk kamu. dan janganlah kamu memilib yang buruk-buruk lalu kamu menafkabkan daripadanya, Padahal kamu sendiri tidak mau mengambilnya melainkan dengan memincingkan mata terhadapnya. dan ketabuilah, bahwa Allah Maha Kaya lagi Maha Terpuji"."

Dalam suatu riwayat dikemukakan, bahwa turunnya ayat tersebut di atas berkenaan dengan kaum Anshar yang mempunyai kebun kurma. Ada yang mengeluarkan zakatnya sesuai dengan penghasilannya, tetapi ada juga yang tidak suka berbuat baik, mereka menyerahkan kurma yang kualitas rendah dan busuk, maka

\footnotetext{
${ }^{26}$ Q.S. al-Taubah : 103.

${ }^{27} \mathrm{Ibnu}$ al-Arabi, Tafsir al-Thabari, (Beirut: Dar al-Fikr, tt), juz IV, h. 123.

${ }^{28}$ Muhammad ibn Ahmad ibn Abi Bakar Al-Qurthubi, al-Jami' li Abkam al-Quran (Tafsir al-Qurthubi), (Kairo: Dar al-Sya'b, 1372 H.), juz VIII, h. 246.

${ }^{29}$ Q. S al-Baqarah : 267. Ayat ini tidak termasuk yang ditafsirkan oleh Muhammad Ali al-Sayis. Sewaktu menafsirkan surat al-Baqarah terjadi loncatan, yakni dari ayat 242 langsung ke ayat 275. Lihat : Muhammad Ali al-Sayis, Tafsir Ayat al-Ahkam, (Tk.: Tp., Th), h. 161. Sedangkan Muhammad Ali al-Shabuni pun melakukan loncatan, yakni dari ayat 237 ke ayat 275. Artinya ayat ini tidak juga termasuk ayat yang ditafsirkan. Lihat : Muhammad Ali al-Shabuni, Rawai' al-Bayan Tafsir Ayat Abkam Min al-Qur'an, (Makkah al-Mukarramah : Dar ash-Shabuni. Th), h.369 dan 382. Di pihak Lain; Muhammad Amin Suma mengutip ayat ini dalam bukunya Menggali Akar Mengurai Serat Ekonomi \& Kenangan Islam, namun tidak satu kali pun dikaitkannya dengan apa yang diistilahkan dengan zakat. (Baca halaman 2008).
} 
turunlah ayat tersebut sebagai teguran atas perbuatan mereka. ${ }^{30}$ Dalam riwayat lain dikemukakan bahwa ada orang-orang yang memilih kurma yang jelek untuk dizakatkan, maka turunlah ayat ini sebagai teguran atas perbuatan mereka. ${ }^{31}$

Riwayat lain dikemukakan bahwa Nabi Muhammad SAW memerintahkan berzakat fitrah dengan satu gantang kurma. Pada waktu itu datanglah seorang laki-laki membawa kurma yang sangat rendah kualitasnya, maka turunlah ayat tersebut di atas sebagai petunjuk supaya mengeluarkan yang baik dari hasil usaha. ${ }^{32}$ Dalam riwayat lain dikemukakan bahwa para sahabat Nabi Muhammad SAW ada yang membeli makanan yang murah untuk disedekahkannya, maka turunlah ayat di atas sebagai petunjuk bagi mereka. ${ }^{33}$

Pada surat al-Baqarah ayat 267 di atas, lafaz "ma" adalah termasuk kata yang mengandung pengertian yang umum, yang artinya "apa saja". Dengan demikian yang dimaksud oleh lafal dan sebagai suatu yang dikenai kewajiban zakat tersebut adalah apa saja yang diperoleh dari yang diusahakan (hasil usaha) dan apa saja yang diperoleh dari hasil bumi.

Kata " $m a$ " (ا) yang terdapat dalam ayat di atas adalah "isim maushup" yang diartikan dengan "alladriy" (الذي). ${ }^{34}$ Sewaktu menjelaskan siyagh al-umum (bentukbentuk kata yang bermakna umum) dalam kajian Ushul Fiqh disebutkan, bahwa "isim maushul" termasuk salah satunya. ${ }^{35}$ Berarti ayat ini menjelaskan apa saja kekayaan kekayaan yang dimiliki, bersumber dari kegiatan ekonomi dan hasil bumi asalkan termasuk dalam kelompok thayyibat.

Al-Jashshash mengatakan, bahwa maksud dari firman Allah SWT yang

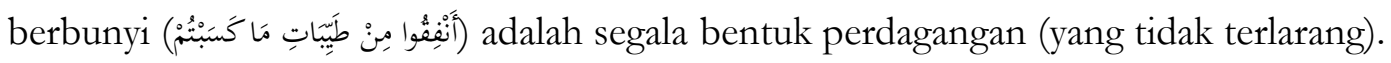
${ }^{36}$ Sedangkan maksud firman Allah SWT (ونما أخرجنالكم من الأرض) berlaku umum dalam kewajibannya, baik penghasilannya sedikit maupun penghasilannya besar. ${ }^{37}$

Al-Harasi mengemukakan bahwa ada sekelompok orang yang beralasan untuk menguatkan pendapat Imam Abu Hanifah sewaktu menafsirkan firman Allah SWT (وميا أخرجنالكم من الأرض) dengan mengatakan, bahwa kalimat ini memfaedahkan umum, yakni apa saja yang dihasilkan oleh bumi, baik sedikit maupun banyak. Mereka juga berpendapat bahwa makna amar di sini adalah untuk wajib, sesuai dengan zhahirnya (asalnya), namun pemahaman ini jauh dari kebenaran. ${ }^{38}$

${ }^{30}$ Qamaruddin Shaleh, dkk., Asbabun Nuzul, (Bandung: CV Diponegoro, Tt), h.82.

${ }^{31}$ Ahmad Mushthafa al-Maraghiy, Tafsir al-Maraghiy, Juz 3, (Beirut: Dar Ihya' at-Turats al-'Arabiy, Tt), h. 39 .

${ }^{32} \mathrm{Abu}$ al-Hasan Ali Ibn Ahmad al-Wahidi al-Naisaburi, Asbab al-Nuzul, Jakarta : Dinamika Berkah Utama, Tt.), h.56.

${ }^{33}$ Ibid.

${ }^{34}$ Umar Taufiq Safr Agha, al-Mu'jam fi al-I'rab, (Dar al-Baidha' : Dar al-Ma'rifah, 1992), h.134.

${ }^{35}$ Wahbah az-Zuhailiy, Ushul al-Figh al-Islamiy, (Damaskus: Dar al-Fikr, 1986), Juz I, h. 248.

${ }^{36}$ Al-Jashshash, Abkam al-Qur'an, (Beirut: Dar al-Fikr, 1993), juz I, h.624.

${ }^{37}$ Ibid., h.625.

${ }^{38}$ Ilkiya al-Harasiy, Abkeam al-Qur'an.(al-Maktabah al-Syamilah). 
Sesungguhnya yang dimaksud oleh ayat itu adalah penjelasan tentang kekayaan yang didalamnya tersangkut dengan hak Allah SW'T, bukanlah maksudnya untuk menyebutkan ukuran harta apa saja yang di dalamnya ada suatu kewajiban. Dan bukan pula menjelaskan harta benda apa saja yang wajib dizakati. Karenanya dalam ayat ini tidak pula disebutkan nisab harta yang wajib dizakati tersebut, tidak pula disebutkan jenis usaha apa saja yang tergantung zakat di dalamnya, sekalipun tidak semua hasil usaha itu wajib dizakati. Argumentasi mereka ini jelas keluar dari maksud ayat. ${ }^{39}$

Sewaktu menafsirkan ayat ini al-Syaukani mengatakan bahwa yang dimaksud dengan kalimat "min thayyibati ma kasabtum" adalah hasil usaha yang baik dan pilihan. Jama'ah berkata : sesungguhnya kata "al-thayyibat" di sini berarti halal. Namun boleh saja digabung keduanya, yakni baik dan halal. Sedangkan yang dimaksud dengan kalimat "mimma akhrajna lakum mina al-ardb" adalah tanaman, barang tambang dan rikaz (harta Karun). ${ }^{40}$

Ahmad Musthafa al-Maraghi mengatakan bahwa maksud ayat di atas adalah infaqkanlah yang baik-baik dari harta kamu yang kamu usahakan; terdiri dari mata uang, barang dagangan, binatang ternak, serta apa saja yang dihasilkan bumi, yang terdiri dari biji-bijian, buah-buahan dan lain-lain. ${ }^{41}$

Al-Qur'an sebagai dasar yang mewajibkan zakat tidak merinci jenis harta kekayaan yang wajib dizakati. Al-Qur'an hanya menggunakan lafaz yang umum, yaitu amwal yang bermakna segala macam harta, meskipun dalam hadis Nabi Muhammad SAW telah menyebutkan beberapa nama dan jenis harta yang wajib dizakati seperti al-masyizah (beberapa jenis hewan), al-zahab-fidhdhah (emas-perak), 'urud al-tijarah (harta perdagangan), zuru' simar (hasil pertanian dan tumbuhan tertentu), dan rikaz-ma'din (harta temuan dan galian), tetapi tidak membatasi (takhsis) nama dan jenis harta kekayaan selain dari lima macam di atas, seperti zakat hasil laut dan zakat profesi. ${ }^{42}$

Berkaitan dengan zakat hasil serikat usaha yang ditunjukkan oleh kata "kasabtum", maka hasil usaha yang dimaksud, seperti yang juga telah diuraikan di atas, dapat dikelompokkan pada dua bentuk, yaitu; usaha yang bersifat harta benda (maliyah) dan usaha yang bersifat manfaat atau pengelolaan jasa. Pada ayat ini juga digunakan kalimat jama' "kasabtum", harta hasil usaha kalian. Kata kalian (ك) disini dapat berarti sejumlah individu dari kalian dan dapat pula diartikan beberapa individu yang bergabung di antara kalian. Oleh karenanya, sebagaimana pembahasan sebelumnya tentang kalimat 'mereka' (ه), dimensi dan orientasi dari kalimat 'kalian' ini juga mencakup harta hasil usaha bersama atau disebut juga dengan harta syirkah usaha.

\footnotetext{
${ }^{39} \mathrm{Ibid}$.

${ }^{40}$ Muhammad Ibn Ali Ibn Muhamma al-Syaukaniy, Fath al-Qadir, (Beirut: Dar al-Fikr, 1973), Juz I,

${ }^{41}$ Ahmad Mushthafa al-Maraghiy, loc.cit.

${ }^{42}$ Wahbah al-Zuhaili, Fiqh al-Islami wa Adillatubu, (Damsyik, Dar al-Fikr, 1989), Cet III, Jilid II, h. 758. Lihat pula; Yusuf al-Qardhawi, Figh al-Zakah, op.cit., h. 456.
} h.289. 
Hal senada juga dinyatakan oleh Raghib al-Asfahani, bahwa kata "al-kasab" tersebut berarti :

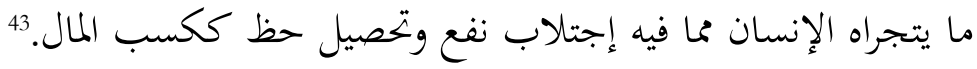

"Apa saja yang diperbuat oleh manusia berupa perdagangan dan usaha yang mendatangkan manfaat dan menghasilkan keuntungan adalah seperti perdagangan harta".

Kata "ma kasabtum" sebagaimana yang disebutkan dalam ayat di atas, merupakan kata umum yang artinya mencakup segala macam bentuk usaha. Dengan demikian, berarti segala macam usaha perdagangan atau pekerjaan dan profesi telah tercakup dalam keumuman maksud ayat tersebut, sesuai dengan kaidah ushul fikih:

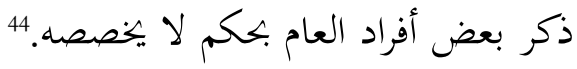

"Menyebutkan sebagian afrad yang umum, tidak berarti mengkhususkan makna yang umum".

Menurut Muhammad Rasyid Ridha bahwa ayat tersebut di atas adalah tentang harta yang wajib dizakatkan, yaitu sebagian harta yang dihasilkan oleh manusia dengan jalan usaha, seperti perdagangan, perusahaan dan sebagainya. ${ }^{45}$ Abu Ja'far Muhammad ibn Jarir al-Thabari berkomentar tentang kalimat tersebut menyatakan perintah Allah SWT tentang kewajiban mengeluarkan zakat dari hasil usaha perdagangan atau perusahaan. Sedangkan yang dimaksud dengan kata "tayyibat" adalah yang baik zatnya dan halal cara mendapatkannya. ${ }^{46}$ Imam Jashas menyatakan bahwa menurut ulama salaf yang dimaksud dengan "hasil usaha kalian" dalam ayat di atas adalah hasil usaha perdagangan. ${ }^{47}$

Lafaz "ma" di dalam surat al-Baqarah ayat 267 di atas, tidak menyebutkan secara rinci tentang materi apa saja yang dikenakan kewajiban zakat; ayat tersebut masih bersifat global (mujmal). Mengenai objek zakat yang lebih rinci dinyatakan dalam hadis-hadis Nabi Muhammad SAW, seperti yang telah diuraikan dalam pembahasan sebelumnya. Secara eksplisit hadis Nabi Muhammad SAW menyebutkan beberapa jenis harta yang termasuk objek zakat, yaitu; emas dan perak, hasil tanam-tanaman dan tumbuhtumbuhan, hewan ternak, harta terpendam, barang tambang dan perdagangan. Sedangkan di luar itu, tidak ditentukan dalam hadis Nabi Muhammad SAW. Padahal di zaman modern ini banyak terdapat bentuk-bentuk sumber perekonomian (usaha) lain yang tidak tercakup dalam keumuman ayat dan perincian hadis-hadis Nabi Muhammad SAW tersebut.

${ }^{43}$ Raghib al-Ashfahani, Mu'jam Mufradat al-Alfaz al-Qur'an, (Beirut: Dar a-Fikr, t.th), h. 447.

${ }^{44}$ Abd al-Hamid Hakim, al-Bayan, (Jakarta: Sa'diyah Putra, t.th), h. 49.

${ }^{45}$ Muhammad Rasyid Ridha, Tafsir al-Manar, (Beirut: Dar al-Fikr, tt), juz IV, h. 235.

${ }^{46} \mathrm{Abu}$ Ja'far Muhammad ibnu Jarir al-Thabari, Tafsir al-Thabari, (Beirut: Dar al-Fikr, tt), juz IV, h. 156.

${ }^{47}$ Al-Jashas, Abkam al-Qur'an, op cit, Jilid I, h. 543. 
Karena ayat-ayat yang menerangkan tentang zakat tersebut berbentuk lafal yang menyebutkan secara global (mujmal), maka dibutuhkan penjelasan dan perincian dari hadis-hadis Nabi Muhammad SAW, yang dalam hal ini berfungsi sebagai penjelas dan penegas (bayan).

Ibnu al-Arabi mengemukakan bahwa "ada dua pendapat tentang makna dari alnafaqah dalam ayat di atas, yaitu :

a. Nafaqah yang dimaksud adalah sedekah wajib. Demikian menurut 'Ubaidah alSalmaniy dan lainnya.

b. Nafaqah yang dimaksud adalah berlaku umum untuk semua sedekah - baik sedekah wajib maupun sedekah sunnat. ${ }^{48}$

Pendapat yang benar menurut Ibnu al-Arabi adalah yang mengatakan bahwa makna al-nafaqah dalam ayat ini berlaku umum, baik yang wajib maupun yang sunnat. ${ }^{49}$ Pendapat yang sama juga dikemukakan oleh Ilkiya al-Harasi - dari kalangan al-Syafi'iy. Namun ia menambahkan, bahwa bila yang dimaksudkan termasuk nafkah sunnat disebutkannya sebagai berikut :

$$
\text { ومن جهة أخرى, وهو أن في النفل أداء القليل والكثير والجيد والرديء. }
$$

"Dilihat dari sisi lain, bahwa bila yang dimaksud di sini nafkah sunnat maka disunnatkanlah membayarkannya, baik sedikit maupun banyak, baik yang bagus maupun yang tidak bagus". ${ }^{50}$

Muhammad Amin Suma mengutip keterangan Ibnu Qayyim al-Jauziyah ketika menafsirkan ayat di atas antara lain menyatakan bahwa penyebutan kedua sumber ekonomi yaitu yang keluar (berasal) dari perut bumi (al-kharij min al-ardh) dan yang dihasilkan melalui usaha ekonomi (al-hashil bikasb al-tijarab), dengan tidak menyertakan sumber-sumber yang lain seperti peternakan dan pertambangan, boleh jadi karena didasari dua hal utama :

Pertama, berdasarkan kondisi objektif aktifitas ekonomi yang dilakukan masyarakat Arab waktu itu, yang pada umumnya hanya terdiri atas perniagaan atau perdagangan dan perkebunan atau pertanian. Perniagaan dan perdagangan, pada umumnya dipegang oleh kaum Muhajirin (imigran dari Mekkah), sedangkan perkebunan atau pertanian kebanyakan didominasi oleh penduduk Anshar (asli Madinah).

Kedua, penyebutan hasil bumi dan usaha ekonomi pada ayat di atas sangat dimungkinkan dihubungkan dengan asal usul kehartabendaan dan kekayaan lainnya yang berasal dari keduanya dan dari keduanya itu pula kemudian ditumbuh kembangkan kekayaan. Termasuk ke dalam pengertian al-kasbu ialah perniagaan dan perdagangan dengan berbagai macam bentuk dan jenisnya, dan termasuk ke dalam kategori nyang dihasilkan dari dalam bumi ialah biji-bijian dan buah-buahan serta barang-barang tambang dan lain sebagainya. Kedua sumber ekonomi inilah yang

${ }^{48}$ Abu Bakar Muhammad Ibn Abdillah Ibn al-Arabiy, Abkam al-Qur'an, (Beirut: Dar Ihya' at-Turats al'Arabiy, T.th)., Juz.I, h.234.

${ }^{49}$ Ibid.

${ }^{50}$ Ilkiya al-Harasiy, Abkam al-Quran.(al-Maktabah al-Syamilah). 
menjadi asal usul harta kekayaan di muka bumi pada umumnya, dan itulah pula sebabnya mengapa penyebutan keduanya secara eksplisit dalam al-Quran dianggap sangat penting. ${ }^{51}$

Rasulullah SAW bersabda yang secara tersurat menyebutkan kata al-kash tersebut, sebagai berikut :

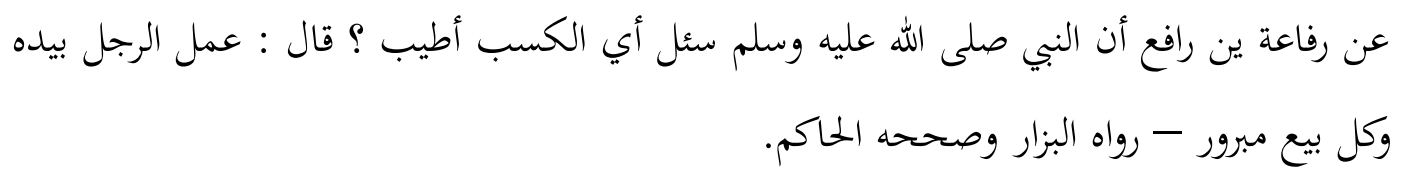

(Hadis yang berasal dari Rifa'ah Ibn Rafi', bahwa Nabi SAW pernah ditanya tentang usaha ekonomi apa yang paling baik ? Rasulullah menjawab : Pekerjaan seseorang dengan tangannya sendiri dan setiap jual beli yang mabrur). ${ }^{52}$

Menurut al-Kahlani bahwa Hadis di atas pada dasarnya menunjukkan pengakuan terhadap eksistensi pekerjaan yang secara alamiah tergolong ke dalam salah satu bentuk usaha ekonomi. Pertanyaan yang diajukan Rifa'ah kepada Nabi Muhammad SAW tentang jenis pekerjaan mana yang terbaik, itu semata-mata lebih mengacu kepada jenis pekerjaan yang kualitas kehalalan dan keberkahannya dianggap lebih dibandingkan dengan kualitas kehalalan dan keberkahan yang terdapat dalam jenis-jenis pekerjaan yang lain. ${ }^{53}$

Dengan kalimat lain Hadis di batas sama sekali tidak bermasud untuk hanya mengakui dua macam usaha ekonomi (عمل الرجل بيده وكل بيع مبرور) dengan mengingkari keberadaan usaha-usaha ekonomi lainnya, akan tetapi hanya untuk membandingbandingkannya dengan jenis-jenis usaha ekonomi yang lain. ${ }^{54}$

Selanjutnya Amin Suma mengatakan, seperti disimpulkan al-Mawardi (w.450 H.), dalam ilmu ekonomi Islam klasik, dasar-dasar al-makasib (usaha ekonomi) biasa dibedakan ke dalam tiga macam, yaitu : (i) al-Zira'ah / pertanian. (ii) al-Tijarah/ perniagaan temasuk perdagangan, dan (iii) al-Shin'ah / perindustrian. ${ }^{55}$

Pemilaan jenis pekerjaan (al-makasib/al-a'mal) oleh al-Mawardi ini pada dasarnya tampak masih sejalan dengan pembagian pekerjaan yang diberikan oleh ahliahli ekonomi Islam zaman modern kini. Sekurang-kurangnya menurut Muhammad Rawwas Qal'ah, juga membagi al-a'mal (usaha ekonomi), dalam konteks pertambahan modal (istitsmar ra's al-mal) dan pertumbuhan sektor ril (al-tanmiyyah al-haqiqiyyah) kedalam tiga macam yakni : (i) al-Istikhrajiyah (ii) al-Tahwiliyyah dan (iii) al-Khadamat. ${ }^{56}$

Sangat layak dicatatkan di sini bahwa di zaman Rasulullah SAW dan bahkan pada masa-masa khalifah nyang menggantikannya, ulil amri (pemerintah) tidak

\footnotetext{
${ }^{51}$ Muhammad Amin Suma, Menggali Akar Mengurai Serat Ekonomi \& Kenangan Islam, (Jakarta : Kholam Publishing, 2008), h.206.

${ }^{52}$ Muhammad Ibnu Ismail al-Kahlaniy, Subul al-Salam, (Tk: Tp., T.th), Juz.II, h,. 4.

${ }^{53}$ Amin Suma, op.cit., h. 207.

${ }^{54}$ Ibid.

${ }^{55}$ Ibid.

${ }^{56}$ Ibid.
} 
melakukan kegiatan usaha ekonomi secara langsung, katakanlah semacam Badan Usaha Milik Negara (BUMN) atau Badan Usaha Milik Daerah (BUMD) yang dilakukan oleh pemerintahan sekarang. Nabi Muhammad SAW memberikan kebebasan kepada masyarakat luas untuk melakukan aktifitas ekonomi. Kebijakan ekonomi makro yang dilakukan oleh Rasulullah SAW lebih mengarah kepada hukum dan etika ekonomi yang harus dilaksanakan dan dihormati oleh semua pelaku ekonomi (konsumen maupun pedagang)..$^{57}$

Di sisi lain ada hal menarik bila kata-kata yang digunakan dalam ayat ini dibedah dengan teori analisis al-Zhahiriyah. ${ }^{58}$ Teori dimaksud adalah apa yang mereka istilahkan dengan dalil. Bila ada suatu kata yang dapat dikembangkan darinya pengertian yang sangat banyak dan berlaku umum, maka perlu dipertahankan pengertian tersebut-tanpa harus mempergunakan qiyas dan lainnya-. Umpamanya firman Allah SWT dalam surat Ali Imran ayat 185, sebagai berikut :

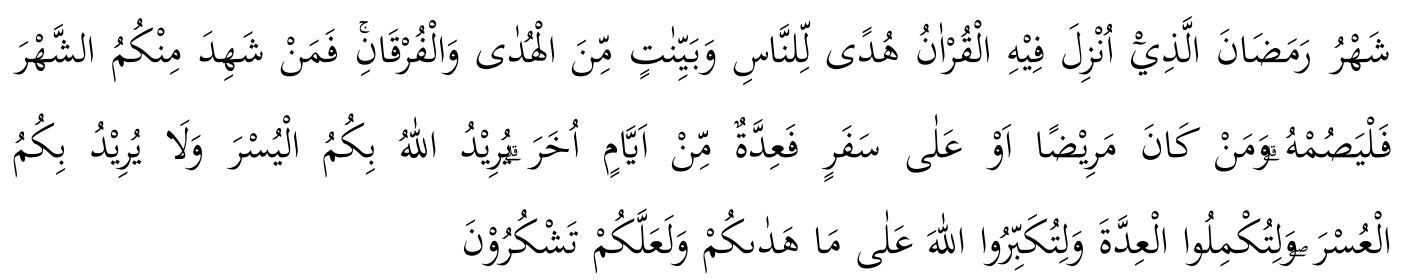

"Tiap-tiap yang berjiwa akan merasakan mati. dan Sesunggubnya pada hari kiamat sajalah disempurnakan pahalamu. Barangsiapa dijaubkan dari neraka dan dimasukkan ke dalam syurga, Maka sunggub ia telah beruntung. kehidupan dunia itu tidak lain hanyalah kesenangan yang memperdayakan". ${ }^{5}$

Dapat disimpulkan darinya, bahwa si Zaid akan mati, si Hindun akan mati, si 'Amr juga akan mati. Pokoknya menjadi batasan adalah "setiap yang bernyawa", sekalipun tidak disebutkan ayat rinciannya. ${ }^{60}$

Dengan demikian dapat disimpulkan bahwa batasan kekayaan atau harta benda yang wajib dizakati itu adalah thayyibat-nya, dengan tidak perlu lagi mempersoalkan sumbernya, apakah berasal dari usaha ekonomi atau yang dihasilkan bumi. Baik yang sudah pernah ada hasil usaha serupa di zaman Nabi Muhammad SAW atau pun tidak. Pokoknya pemahaman ini akan tetap mengikat, sekalipun ada perubahan waktu dan tempat.

\section{KESIMPULAN}

Berlandaskan kepada penjelasan di atas mulai penjelasan ayat sampai kepada kata-kata yang dipergunakan sewaktu membicarakan harta benda tersebut, maka kesimpulan utama

${ }^{57}$ Ibid., h.208.

${ }^{58}$ Adalah suatu mazhab hukum yang berpatokan pada lahir nash saja. Tokoh pendirinya adalah Daud azh-Zhahiriy, lalu dikembangkan dan disebar luaskan oleh pengikutnya yang bernama Ibn Hazm di Andalus. Mazhab ini sangat keras menolak qiyas sebagai dalil hukum.

${ }^{59}$ Q.S. Ali Imran : 185.

${ }^{60} \mathrm{Abu}$ Muhammad Ali Ibn Ahmad Ibn Sa’id Ibn Hazm Azh-Zhahiriy, Al-Ihkam fi Ushul al-Ahkam, (Beirut: Dar al-Kutub al-'Ilmiyah, T.th)., Juz I1, h. 101. 
penelitian ini ialah : Kekayaan yang dimiliki seseorang yang bersumber dari usaha ekonomi apa saja usahanya dengan batasan thayyibat (halal dan bermanfa'at), wajib-lah ia mengeluarkan sebagian dari penghasilannya bagi keperluan orang yang berhak menerimanya.

\section{REFERENSI}

Abu Zaid, Ahmad, At-Tanasub al-Bayaniy fi al-Quran, Dar al-Baidha' : Mathba'ah an-Najah al-Jadidah, 1992.

Ahmad, Mustaq, Etika Bisnis Dalam Islam, Terjemahan Samson Rahman, Jakarta, Pustaka Al-Kautsar, 2001.

Ali, Mohammad Daud, Lembaga-lembaga Islam di Indonesia, Jakarta, Raja Grafindo Persada, 1995.

Anonim, Al-Qur'an dan Terjemahnya, Madinah, Malik Fahd, 2002.

Kamus Besar Bahasa Indonesia, Jakarta, Balai Pustaka, 1990.

, Hasil Seminar Seminar Internasional Zakat I Tanggal 29 Rajab 1404 / 3 April 1984, di Kuwait.

, Undang-Undang Republik Indonesia Nomor 23 Tabun 2011 Tentang Pengelolaan Zakat.

Antonio, Muhammad Syafi'i, Bank Syariah Wacana Ulama \& Cendikiawan Jakarta, Bank Indonesia, 1999.

Ashiddiqie, Jimly, Perkembangan dan Konsolidasi Lembaga Negara Pasca Reformasi, Jakarta, Setjen dan Kepaniteraan MKRI, 2006.

Agha, Umar Taufiq Safr, Al-Mu'jam fi al-I'rab, (Dar al-Baidha' : Dar al-Ma'rifah, 1992.

Al-Arabiy, Abu Bakar Muhammad Ibn Abdillah Ibn, Abkam al-Qur,an, Jld.1, Beirut : Dar Ihya' at-Turats al-'Arabiy, TT.

Al-Ashfahaniy, Ar-Raghib, Mufradat Alfaz, al-Quran, Damaskus : Dar al-Qalam, TT.

Al-Fanjariy, Muhammad Syauqy Al-Islam wa adh-Dhaman al-Ijtima'iy, Riyadh : Dar ats-Tsaqif, 1980.

Djalil, Ramlie, Peranan ZIS dalam Pemberdayaan Ekonomi Umat, Jambi, BAPPEDA, 1998.

Ghazali, H.M. Syukri dkk, Pedoman Zakat, Jakarta: Proyek Pembinaan Zakat dan Wakaf, 1991.

Hakim, Abd al-Hamid, al-Bayan, (Jakarta: Sa'diyah Putra, t.th), h. 49.

Al-Harasiy, Ilkiya, Abkam al-Quran. (al-Maktabah asy-Syamilah).

Ibn al-Arabi, Tafsir al-Thabari, Beirut: Dar al-Fikr, tt, juz IV. 
Ibnu Daqiqi al-'Id, Ihkam al-Ahkam Syarah Umdah al-Ahkam, Beirut: Dar al-Kutub al-Ilmiyah, tt, Jilid I.

Ibnu Hajar al-Asqalani, Fath al-Bari Syarah Shabih al-Bukhari, Beirut: Dar al-Fikr, 1991, Jilid IV:

Ibn Katsir, Abu al-Fida' Ismail, Tafsir al-Quran al-'Az̧him, Jld 1, Mesir : Isa al-Halbiy,

Ibn Manzur, Abi al-Fadhl Jamaluddin ibn Makram, Lisan al-Arab, Bairut, Dar al-Shadir, li al-Thiba'ah wa al-Nasyr, t.th, Jilid XI.

Ibnu Rusyd, Muhammad bin Ahmad al-Qurtubi, Bidayah al-Mujtahid wa Nihayah al-Muqtasid, Mesir, Musthafa al-Baby al-Halaby, 1370 H / 1950 M.

Al-Jashshash, Abkam al-Quran, Jld 1, Beirut : Dar al-Fikr, 1993.

Al-Jurjaniy, Kitab at-Ta'rifat, Beirut : Dar al-Kitab al-'Arabiy, 1992.

Al-Kahlaniy, Muhammad Ibn Ismail, Subul as-Salam, Jld.2, TK.: TP., TT.

Al-Khalil an-Nahwiy, Al-Mu'jam al-'Arabiy al-Muyassar, Tunis : Bitha,

Al-Maraghiy, Ahmad Mushthafa, Tafsir al-Maraghiy, Juz 3, Beirut : Dar Ihya' at-Turats al'Arabiy, TT.

Mausu'ah al-Hadis al-Syarif, Edisi II, tahun 2000 (1991-1997), Syirkah al-Baramij alIslamiyyah al-'Alamiyyah, sistem penomoran internasional.

Muhammad ibn Muhammad ibn Muhammad al-Ghazali, Abu Hamid, al-Wasith fi alMą̧ab, Kairo: Dar al-Salam, 1417, juz VI.

Muslim, Musthafa, Mabahits fi at-Tafsir al-Mawdbu'iy, Damaskus : Dar al-Qalam, 1997.

Al-Naisaburiy Abu al-Hasan Ali Ibn Ahmad al-Wahidiy, Asbab an-Nuzul, Jakarta : Dinamika Berkah Utama, TT

Nuruddin, Amiur, Jamuan Ilahi Pesan al-Quran dalam Berbagai Dimensi Kehidupan, Bandung : Citapustaka Media, 2007.

Qadir, Abdurrahman, Zakat (Dalam Dimensi Mabdhah dan Sosial), Jakarta, Raja Grafindo Persada, 2001, Cet II.

Qardhawi, Yusuf, Al-. Fiqh al-Zakah, Beirut, Muassasah al-Risalah, 1994, Juz I.

Qosim bin Salam, Abi Ubaid, Kitab al-Amwal, Kairo, Dar al-Fikr, 1975.

al-Qurthubi, Muhammad ibn Ahmad ibn Abi Bakar, al-Jami' li Abkam al-Quran (Tafsir alQurthubi), Kairo: Dar al-Sya'b, 1372 H, juz VIII.

Ridha, Muhammad Rasyid, Tafsir al-Manar, Beirut: Dar al-Fikr, tt, juz IV.

Sabiq, Sayyid, Fiqh al-Sunnah, Beirut, Dar al-Fikr, 1983, cet. II, juz I dan III.

Saefuddin, Ahmad Muflih, Pengelolaan Zakat Ditinjau dari Aspek Ekonomi, Bontang, Badan Dakwah Islamiyah LNG, 1986. 
Al-Sayis, Muhammad Ali, Tafsir Ayat al-Ahkam, TK. : TP., TT.

Shaleh, Qamaruddin, dkk., Asbabun Nuæul, Bandung : CV Diponegoro, 'TT.

Al-Shabuniy, Muhammad Ali, Rawai' al-Bayan Tafsir Ayat Abkam Min al-Quran, Makkah alMukarramah : Dar ash-Shabuniy. TT

Al-Shadr, Muhammad Baqir, At-Tafsir al-Mawdh''iy wa al-Falsafah al-Ijtima'izyah fi al-Madrasah al-Quraniyyah, Beirut : Ad-Dar al-'Alamiyyah, 1989,

Suma, Muhammad Amin, Menggali Akar Mengurai Serat Ekonomi \& Kenangan Islam, Jakarta : Kholam Publishing, 2008,

------------, Pengantar Tafsir Abkam, Jakarta : PT Raja Grafindo Persada, 2002.

Syafi'i, Muhammad Ibn Idris, Abu Abdullah, al-, al-Umm, Beirut, Dar al-Ma'rifah, 1393, cet II, juz II.

Syafe'i, Rachmat, Ilmu Ushul Fiqih, Bandung, Pustaka Setia, 2007.

Syah, Ismail Muhammad, Filsafat Hukum Islam, Jakarta: Bumi Aksara, 1992.

Syalabi, Ahmad, Tarekh al-Tasyri' al-Islami, Kairo, Maktabah al-Nahdhah al-Misriyah, t.t, juz I.

Al-Syaukaniy, Muhammad Ibn Ali Ibn Muhamma, Fath al-Qadir, Jld 1, Beirut : Dar al-Fikr, 1973.

Syaukani, Muhammad Ali Muhammad, Al-. Nail al-Autar, Juz. VII, Mustafa al-Babiy alHalabiy, Mesir, tt.

al-Thabari, Abu Ja'far Muhammad ibnu Jarir, Tafsir al-Thabari, Beirut: Dar al-Fikr, tt, juz IV.

Unais, Ibrahim, dkk, Al-Mu'jam al-Wasith, Istambul : Al-Maktabah al-Islamiyyah, TT.

Zakaria ibn Muhammad ibn Ahmad ibn Zakaria al-Anshari, Fath al-Wabhab bi Syarb Manhaj al-Thullab, Beirut: Dar al-Kutub al-Ilmiyyah, 1418, juz II.

Al-Zhahiriy, Abu Muhammad Ali Ibn Ahmad Ibn Sa'id Ibn Hazm, Al-Ihkam fi Ushul alAbkam, Jld.I1, Beirut : Dar al-Kutub al-'Ilmiyah, TT.

Al-Zuhaili, Wahbah, Al-. Figh al-Islami wa Adillatubu, Damsyik, Dar al-Fikr, 1989, Cet III, Juz I, II, III, IV, V.

Ushul al-Fiqh al-Islamiy, Juz 1, Damaskus : Dar al-Fikr, 1986, h.248. 